\title{
Identification of Goats' and Cows' Milk Protein Profile in Banyumas Regency by Sodium Dedocyl Sulphate Gel Electrophoresis (Sds-Page)
}

\author{
Hermawan Setyo Widodo*, Triana Yuni Astuti, Pramono Soediarto and Afduha Nurus Syamsi \\ Faculty of Animal Science, Jenderal Soedirman University, Purwokerto, Indonesia \\ *Corresponding author email: hsw@unsoed.ac.id
}

\begin{abstract}
Protein is one of the nutrient components in milk that is related to product quality. The components of milk protein are divided into casein alpha-s1, beta, alpha-s2, kappa, and whey fractions such as alpha lactalbumin and beta lactoglobulin. There are no existing data of milk protein fraction in dairy cow and goats in Banyumas Regency. This study aimed to determine the profile in form of protein fractions of cow and goat milk in Banyumas. Milk sample from fifty cows and thirty dairy goats was taken by random sampling in some areas. The milk protein profile was identified by the technique of sodium dodecyl sulphate gel electrophoresis (SDSPAGE) and protein quantity prediction by software. The data obtained were analyzed statistically by MannWhitney between cows and goats. The results were significantly different $(p<0.05)$ between cows and goats in molecular weight of protein alpha-S1 casein (29.66 vs $33.37 \mathrm{kDa}$ ), alpha-S2 (27.76 vs $29.49 \mathrm{kDa})$, beta (24, 48 vs $25.59 \mathrm{kDa}$ ) and beta lactoglobulin (15.75 vs $15.97 \mathrm{kDa})$. The quantity of casein alpha-S1 (7.88 vs $4.16 \mathrm{~g} / \mathrm{l})$, alpha-S2 (1.31 vs. $4.02 \mathrm{~g} / \mathrm{l})$, beta ( 8.74 vs $14.24 \mathrm{~g} / \mathrm{l})$ ), kappa ( $2.41 \mathrm{vs.} 4.28 \mathrm{~g} / \mathrm{l}$ ) and alpha lactalbumin (0.91 vs 0.7 $\mathrm{g} / \mathrm{I})$ was significantly different $(\mathrm{p}<0.05)$ between cow's and goat's milk, respectively. In conclusion, milk protein profile of cows and goats in Banyumas Regency is different.
\end{abstract}

Keywords: cows, goat, protein, milk, casein

Abstrak. Protein merupakan salah satu komponen nutrien di dalam susu yang berkaitan dengan kualitas produk yang dihasilkan. Komponen protein susu terbagi menjadi fraksi kasein alfa-s1, beta, alfa-s2, kappa, serta whey berupa alfa laktalbumin dan beta laktoglobulin. Belum terdapat data mengenai fraksi protein tersebut pada ternak sapi dan kambing perah di Kabupaten Banyumas. Penelitian ini bertujuan untuk mengetahui profil berupa fraksi protein susu sapi dan kambing di kabupaten Banyumas. Lima puluh ekor sapi dan tiga puluh ekor kambing perah diambil sampel susu secara acak dari beberapa wilayah. Profil protein susu diidentifikasi menggunakan teknik sodium dodecyl sulphate gel electrophoresis (SDS-PAGE) serta prediksi kuantitas protein dengan bantuan aplikasi komputer. Data yang diperoleh kemudian dianalisis statistik dengan uji beda MannWhitney antara sapi dan kambing. Hasil yang diperoleh yakni terdapat perbedaan nyata $(p<0,05)$ dalam berat molekul protein kasein alfa-S1 (29,66 vs $33,37 \mathrm{kDa})$, alfa-S2 $(27,76 \mathrm{vs} 29,49 \mathrm{kDa})$, beta $(24,48 \mathrm{vs} 25,59 \mathrm{kDa})$ dan beta laktoglobulin $(15,75 \mathrm{vs} 15,97 \mathrm{kDa})$ antara ternak sapi dan kambing. Kuantitas fraksi protein kasein alfa$\mathrm{S} 1(7,88$ vs $4,16 \mathrm{~g} / \mathrm{l})$, alfa-S2 $(1,31$ vs $4,02 \mathrm{~g} / \mathrm{l})$, beta $(8,74$ vs $14,24 \mathrm{~g} / \mathrm{l})$, kappa $(2,41$ vs $4,28 \mathrm{~g} / \mathrm{l})$ dan alfa laktalbumin $(0,91$ vs $0,7 \mathrm{~g} / \mathrm{l})$ berbeda nyata $(p<0,05)$ antara susu sapi dan kambing secara berurutan. Kesimpulan yang diperoleh yakni terdapat perbedaan profil protein susu dari ternak sapi dan kambing di Kabupaten Banyumas.

Kata Kunci: kambing, sapi, protein, susu, kasein

\section{Introduction}

Milk consumption of Indonesian is increasing anually. Awareness in fulfilling the nutritional needs by consuming milk is one of the contributing factors. The consumed products are not only fresh milk but also processed dairy products. Dairy products that available on market vary, such as cheese and yogurt. The consumption of processed products increases with milk consumption, so it potentially benefits the aspects of dairy industry, from the processing to the farmers at the lowest level. These factors demonstrates that the quality and quantity of milk need to be maintained to meet the demand.

Proteins of milk in form of casein and whey fractions affect the quality of dairy products. These proteins are casein fractions, such as alpha-s1, beta, alpha-s2 and kappa, as well as 
dominant whey fractions like alpha lactalbumin and beta lactoglobulin. Various types of processed products are considerably dependent on the milk protein, for example, cheese requires high quality and qantity of milk protein (Damian et al., 2008; Bonfatti et al., 2010). The quality of milk components in the form of casein fraction substantially affects the milk clotting proccess. For instance, a higher quantity of casein kappa has positively reduced the time for cheese coagulation, allowing a faster production process (Prizenberg et al., 2005). Instead of conventional drugs, functional food can even be produced from milk protein fraction to lower high blood pressure (Widodo et al., 2018). These are the challenges in dairy industry in Indonesia.

The potential milk-producing cattle to meet these challenges are dairy cows and goats. Nevertheless, both animals have different profiles of proteins in their milk. Dairy cows are known to produce more alpha-S1 casein than dairy goats. On the other hand, differences in livestock breeds can produce different protein profiles in milk. The example is Saanen dairy goat produces less alpha-S1 casein than Jamnapari dairy goat.

Dairy cows and goats are raised in Banyumas Regency. The population of dairy cattle in Banyumas Regency is about 2,426 heads spread across regions (Pemkab Banyumas, 2018), in contrast with the perceived underdeveloped population of dairy goats. Even so, dairy goats are concentrated in Gumelar sub-district which has regional potential for developing livestock breeding. In addition, Banyumas Regency is a renowned center of milk production in Central Java.

The milk quality in Banyumas district is better than that of other regions with a higher milk production in Central Java (Sudjatmogo et al., 2014). The combined variables of two types of dairy cattle and the superiority of dairy quality in Banyumas district are potentially developed to address the challenges in Indonesian dairy industry.

It takes serious attention to achieve this because data on milk quality, like protein profiles in dairy cows and goats in Banyumas Regency, remains unknown. The data is important for reference in further development of dairy cow and goat farming to meet the needs for protein in the community and to support the national mission of milk selfsufficiency.

Acrylamide gel electrophoresis (Sodium Dodecyl Sulphate - Polyacrylamide Gel Electrophoresis /SDS-PAGE) is one of the strongest assesment methods for analyzing protein fractions in milk (Costa et al., 2013; Kumar et al., 2013) despite the modification or polymorphisms. The method is more robust when aided with computer software to determine the target of protein concentration.

\section{Materials and Methods}

The research location covered Banyumas regency, especially the sub-districts where dairy farming was concentrated, namely Pekuncen, Cilongok and Baturraden for dairy cows and Gumelar for dairy goats. The analysis was carried out at the Dairy Animal Production Laboratory, Faculty of Animal Science, Jenderal Soedirman University, Purwokerto.

The sets of equipment for data analysis were a conical tube, $1.5 \mathrm{ml}$ microtube, pipette tips, bidistilled water, sodium hydroxide, sulfuric acid, Coomasie Brilliant Blue R250, acetic acid, Sodium Dodecyl Sulphate (SDS), acrylamide-bis acrylamide 30\% (29:1), Ammonium Persulphate (APS), TEMED, tris $\mathrm{HCl}$, tris base, glycine, bromophenol blue, glycerol, Bovine Serum Albumin (BSA), protein markers, hydrochloric acid, and urea. The livestock employed in the study were 80 (eighty) heads consisting of 50 dairy cows and 30 dairy goats. The animals were selected by random sampling but perceived to reflect the population and meet the statistical orders. Samples of fresh milk $(100 \mathrm{ml})$ from 
morning and evening milking were taken and composited according to the ratio of the amount of production.

The SDS PAGE gel electrophoresis method refers to the method from Costa et al. (2013). The present study attempted to separate milk fraction protein and analyze the image to determine the molecular weight and quantity of each protein fraction. These parameters could reflect a polymorphism that may affect the following production steps.

The samples were dissolved in $8 \mathrm{M}$ urea solution until approximately $40 \mathrm{mg} / \mathrm{ml}$ protein concentration was obtained using the Bradford method. The samples were dissolved in a $2 \mathrm{X}$ sample buffer $(10 \%$ SDS, $2 \%$ betamercaptoethanol, $\quad 10 \%$ glycerol, $\quad 0.05 \%$ bromophenol blue, pH6.8) with a ratio of 1:1 and heated for 10 minutes at $95^{\circ} \mathrm{C}$. The sample was then cooled and taken $15 \mathrm{ul}$ for separation in a $12 \%$ acrylamide gel pre-filled with running buffer (Tris, glycine and SDS). Each electrophoresis gel running included different samples, namely (1) BSA with a concentration of $10 \mathrm{mg} / \mathrm{ml}$, and $50 \mathrm{mg} / \mathrm{ml}$, (2) milk samples, and (3) Protein markers. The electrophoresis was run at $75 \mathrm{~V}$ for 180 minutes at $15^{\circ} \mathrm{C}$. The process continued by staining $(0.1 \%$ Coomasie Brilliant Blue R250, 10\% acetic acid, 40\% methanol), including washing with distilled water, applying the dye solution for 1 hour, washing with distilled water, and fixing with fixation solution (30\% methanol, $10 \%$ acetic acid). The final gels were placed on a digital scanner and pictures were taken for further analysis. The results of the documentation were analyzed using the Densitometry technique through the Image Lab (Bio-Rad) software. The software could predict molecular weight and relative density of each band which was relatively compared to bands from protein ladders/markers, so each molecular weight was determined. The bands from BSA with different concentrations were calculated as the standard protein quantity by their density and then used to predict the quantity of each protein fraction (Li et al., 2010). The quantity of the target band could be predicted because the software can generate a regression from the standard band data by itself. The obtained data then statistically analyzed using the Mann-Whitney test to compare each fraction between cow and goat milk.

\section{Results and Discussion}

\section{Milk protein molecular weight}

The protein profile in milk is the expression of protein-coding genes in mammary epithelial cells. Protein in milk is substantially diverse, from the most dominant casein to whey. Casein is divided into alpha-S1, alpha-S2, beta and kappa fractions, while the whey consists of the dominant fractions, i.e., alpha lactalbumin, beta lactoglobulin and bovine serum albumine. Milk protein molecular weights between dairy cows and and goats analyzed in this study are presented in the Table 1.

The results of the calculation of the molecular weight of proteins in the milk of dairy cows and goats in Banyumas district showed many differences between alpha-S1 casein, alpha-S2 casein, Beta casein, kappa casein and beta lactoglobuline. However, the contributing factors to these differences were unidentified until further testing. Factors that may influence protein expressions are gene polymorphisms that inspire changes in amino acid sequences from proteins and post translational modifications (PTMs) (Masoodi and Shafi, 2010). The changes in amino acid sequences can occur in the form of deletion, insertion and substitutions initiated by these identical changes in nucleic bases on DNA level. Deletion in these bases may lead to the deletion of several amino acid sequences. 
Table 1. Molecular weight ( $\mathrm{kDa}$ ) of milk proteins of dairy cows and goats in Banyumas regency.

\begin{tabular}{lccc}
\hline \multirow{2}{*}{ Parameters } & \multicolumn{2}{c}{ Animals } & \multirow{2}{*}{ p-value } \\
\cline { 2 - 3 } & Cows & Goats & \\
Casein & & & $<0.01$ \\
$\quad$ Alpha-S1 & $29.66 \pm 0.58$ & $33.37 \pm 0.82$ & $<0.01$ \\
Alpha-S2 & $27.76 \pm 0.71$ & $29.49 \pm 0.94$ & $<0.01$ \\
Beta & $24.48 \pm 0.64$ & $25.59 \pm 1.14$ & 0.03 \\
Kappa & $22.05 \pm 0.21$ & $22.69 \pm 0.87$ & \\
Whey & & & $<0.01$ \\
Betalactoglobuline & $15.75 \pm 0.22$ & $15.97 \pm 0.29$ & 0.89 \\
$\quad$ Alphalactalbumine & $13.68 \pm 0.43$ & $13.70 \pm 0.42$ & \\
\hline
\end{tabular}

On the other hand, insertion may cause the addition of several amino acids sequence in the protein, while substitutions could alter some amino acids without deleting or inserting amino acid sequence. These changes would modify the molecular weight of the protein because each amino acid has different molecular weight (Moatsou et al., 2008). The changes could increase or decrease the molecular weight of protein relatively to its reference of protein molecular weight.

Post-translation modifications (PTMs) is a common phenomenon in proteins, including those on milk. The PTMs is a functional proccess that could change protein properties like molecular weight, point of isoelectric, and active sites. Modification by addition of either the phosphate groups ( phosphorylation) or glucose groups (glycosylation) could increase the protein molecular weight (Masoodi and Shafi, 2010). Some amino acids of milk protein are phosporilated or glycosylated in the golgi apparatus on mammary epithelial cells. The present study observed that different animal showed different PTMs proccess.

\section{Milk protein fraction quantity}

There were significant differences between the parameters in goats' and cows' milk in Banyumas Regency. Alpha-S1 casein in milk produced by cows was higher than dairy goats. It may occur due to differences in genetic expression of alpha-S1 casein which play role in the cheese making process by milk coagulation properties (Bonfatti et al., 2010) because caseins is sensitive to calcium ions in milk. It implies that cheese yield has a positive correlation to casein content in milk.

Alpha-S2 casein in goat milk was four times as high as that of cow milk in Banyumas Regency. Like alpha-S1 casein, alpha-S2 casein is sensitive to calcium ions in milk and, according to Bonfatti et al., (2010), could affect the quality and quantity of cheese yield. If interrelated, cheese from cow milk has a predominant coagulation of alpha-S1 casein while goat milk is from alpha-S2 casein. Genetic diversity may have caused the disparity. There are some alleles that present alpha-S1 casein and alpha-S2 casein which has expression to highly producing casein, but others are low or even zero in producing casein (Caroli et al., 2009).

The quantity of milk beta casein of dairy cows was lower than that of dairy goats in Banyumas Regency. Beta casein is classified as casein that is sensitive to calcium ions in milk, so it is related to the yield quantity of cheese produced (Damian et al., 2008). In addition, beta casein is known to associate with therapeutic properties that produce bioactive peptides (Widodo et al., 2018). There are parts of the beta casein sequence that can produce bioactive peptioda if digested by humans. This has implications to the number of beta casein in goats' milk; the higher the quantity is, the more bioactive peptides are produced. As a result, the therapeutic benefits are optimum. 
Table 2. Quantity (g/l) of milk proteins of dairy cows and goats in Banyumas regency.

\begin{tabular}{lccc}
\hline \multirow{2}{*}{ Parameters } & \multicolumn{2}{c}{ Animals } & \multirow{2}{*}{ p-value } \\
\cline { 2 - 3 } Casein & Cows & Goats & \\
$\quad$ Alpha-S1 & $7.88 \pm 2.48$ & $4.16 \pm 0.99$ & $<0.01$ \\
$\quad$ Alpha-S2 & $1.31 \pm 1.26$ & $4.02 \pm 2.85$ & $<0.01$ \\
Beta & $8.74 \pm 0.03$ & $14.24 \pm 3.31$ & $<0.01$ \\
$\quad$ Kappa & $2.41 \pm 1.08$ & $4.28 \pm 1.07$ & $<0.01$ \\
Whey & & & \\
$\quad$ Betalactoglobuline & $3.42 \pm 1.03$ & $3.15 \pm 0.88$ & 0.21 \\
$\quad$ Alphalactalbumine & $0.91 \pm 0.37$ & $0.70 \pm 0.54$ & 0.046 \\
\hline
\end{tabular}

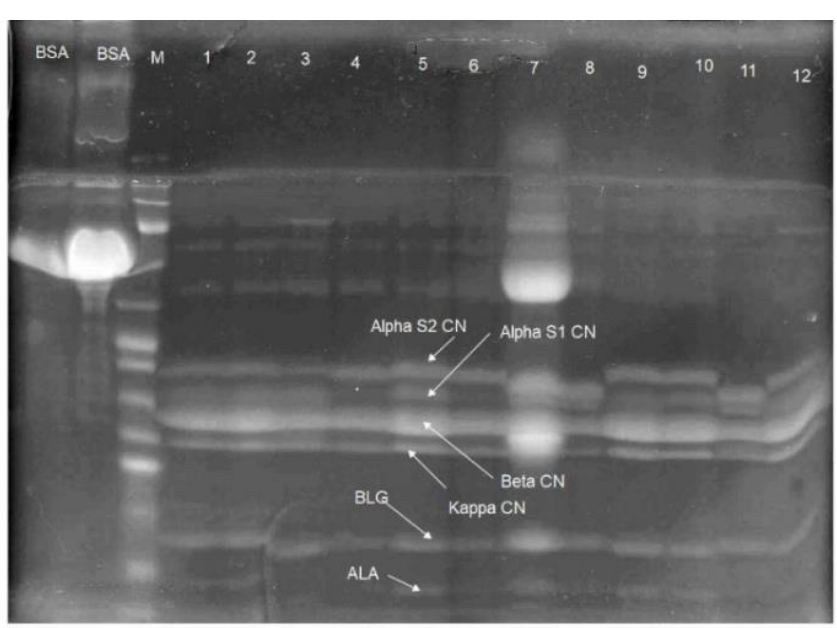

Figure 1. The grayscale documentation of SDS PAGE electorophoresis from cow and goat milk in Banyumas Regency. Note: Goat $(1,2,3,4,5,6,9,10,12)$; Cow (7/coloctrum, 8,11); BSA (1 (10mg/ml) and 2 $(50 \mathrm{mg} / \mathrm{ml})) ; \operatorname{Marker}(\mathrm{M})$.

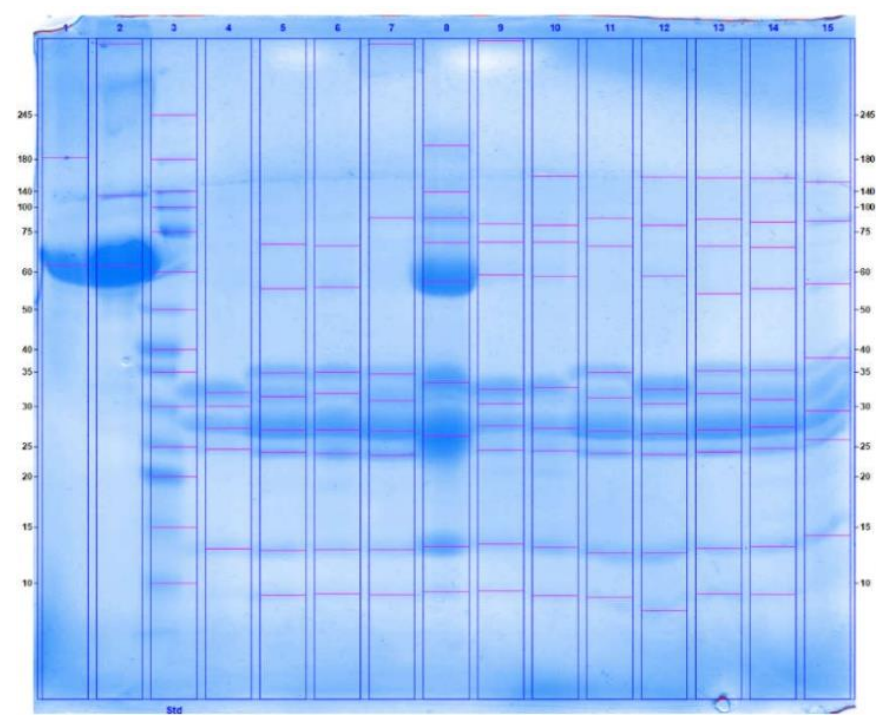

Figure 2. The actual staining colour documentation of SDS PAGE electrophoresis of cow and goat milk in Banyumas Regency. Note : BSA (1 $(10 \mathrm{mg} / \mathrm{ml})$ and $2(50 \mathrm{mg} / \mathrm{ml}))$; Marker (3); Goat $(5,6,7,11,13,14,15)$; Cow $(4,8 /$ colostrum, 9,10,12). 
Kappa casein is a protein in milk that is different from that of other casein. The casein is not sensitive to calcium ions and has hydrophilic characteristic. This protein maintains the stability of casein micelles in milk, so the micelles can dissolve in milk. When the rennet enzyme cleaves kappa casein, the stability decreases and render the casein micelles hydrophobic and adhesive to each other (damian et al., 2008). This aggregation causes coagulation or clumping and has implications to the quality of the cheese produced. The high-expression kappa casein coder gene is known to cause better and denser cheese texture (Bonfatti et al., 2010). Based on these data, goat milk in Banyumas regency may better be processed as cheese compared to cow milk.

The beta lactoglobulin content in goat milk and cow milk in Banyumas regency was not significantly different. It may be related to the similiar expression of the beta-lactoglobulin protein coding gene in the mammary epithelial cells of cow and goats (Moatsou et al., 2008). Beta lactoglobulin has a positive correlation with lactose levels in milk. Lactose content has osmose characteristics, thus increasing the water content in milk then increasing the amount of secreted milk.

The alpha lactalbumin protein content of the two animals is significantly different. It is still related to the expression of coding gene of the protein (Caroli et al., 2009). Alpha lactalbumis is related to the process of milk synthesis in mammary epithelial cells and associated with syneresis or casein gel formation during the coagulation process (Bonfatti et al., 2010). The data shows that the alpha lactalbumin content in cattle is higher than that of dairy goats in Banyumas. This indicates that cow milk in Banyumas potentially produces better syneresis.

\section{Conclusions}

Different molecular weight and quantity of protein fractions were identified between cow and goat milk in Banyumas regency. These differences implied that dairy goats carried the potential milk production to meet the need for dairy product, such as cheese production.

\section{Acknowledgement}

The research was funded by Lembaga Penelitian dan Pengabdian kepada Masyarakat (LPPM) Jenderal Soedirman University with a contract number P351/UN23/14/PN/2019.

\section{References}

Bonfatti,V, GM Di Martino, A Checchinato, L Degano, and P Carnier. 2010. Effects of $\beta-\mathrm{k}$ casein (CSN2-CSN3) haplotypes, $\beta$-lactoglobulin (BLG) genotypes and detailed protein compositionon coagulation properties of individual milk in simmetal cows. Journal of dairy science 93:3809-3817.

Caroli, AM, S Chessa, and GJ Erhardt. 2009. Invited review: Milk protein polymorphisms in cattle: Effect on animal breeding and human nutrition. J. Dairy Sci. 92 :5335-5352. DOI 10.3168/jds.2009-2461.

Costa, FF, MAV P Brito, MAM Furtado, MF Martins, MAL de Oliveira, PM de Castro Barra, LA Garridoc, and AS de Oliveira dos Santos. 2013. Microfluidic chip electrophoresis investigation of major milk proteins: study of buffer effects and quantitative approaching. Analytical Methods. DOI: 10.1039/c3ay41706a

Damian, JP, I Saccji, S Reginesi, D De Lima, and J Bermudez. 2008. Cheese yield, casein fractions and major components of milk of Saanen and Anglo-Nubian dairy goats. Arq. Bras. Med. Vet. Zootec 60(6).

Kumar, A, PK Rout, and BP Mohanty. 2013. identification of milk protein polymorphism in indian goats by 2D gel electrophoresis. J. Of Proteomics and Bioinformatics 6 . DOI 10.4172/jpb.1000252.

Li, K, Z Chen, F Duan, J Liang, and K Wu. 2010. Quantification of tear proteins by SDS-PAGE with an internal standard protein: $A$ new method with special reference to small volume tears. Graefe's Archive for Clinical and Experimental Ophthalmology 248(6):853-862. 
Masoodi, TA, and G Shafi. 2010. Analysis of casein alpha S1 \& S2 proteins from different mammalian species. Bioinformation 4(9):430435.

Moatsou, G, E Moschopoulou, D Molle, V Gagnaire, I Kandarakis, and J Leonil. 2008. Comparative study of the protein fraction of goat milk from the Indigenous Greek breed and from international breeds. Food Chemistry 106(2):509-520.

Pemkab Banyumas. 2018. Banyumas Regency Government: Geographical Location. Online : https://www.banyumaskab.go.id/page/307/let ak-geografis (Visited 1 December 2018).

Prizenberg, EM, K Gutcher, SM Chessa, A Caroli and G Erhardt. 2005. Caprine K-casein (CSN3) polymorphism : New development in molecular knowledge. J. Dairy Sci. 88:1490- 1498.
Sudjatmogo, HS Widodo, and Mukson. 2014. Kajian Tentang Kualitas, Pola Distribusi dan Harga Susu di Kabupaten Banyumas dan Kabupaten Semarang (Study of quality, distribution pattern and price of milk in Banyumas regency and Semarang regency) In Prosiding Seminar Nasional Ruminansia. Semarang. pp : 224-226.

Widodo, HS, TW Murti, A Agus, and W Widodo. 2018. Mengidentifikasi peptida bioaktif Angiotensin Converting Enzyme-inhibitor (ACEi) dari kasein $\beta$ susu kambing dengan polimorfismenya melalui teknik in silico (Identification of angiotensin converting enzyme-inhibitor (ACEi) Bioactive peptide from goat milk $\beta$-Casein with it's polymorphism by in silico technique). Jurnal Aplikasi Teknologi Pangan 7(4). https://doi.org/10.17728 /jatp. 3008. 